\title{
13 DECIDING ON OPEN INNOVATION: An Exploration of How Firms Create and Capture Value with Open Source Software
}

\author{
Lorraine Morgan \\ University of Limerick \\ Limerick, Ireland \\ Patrick Finnegan \\ University College Cork \\ Cork, Ireland
}

\begin{abstract}
Open innovation is a paradigm that proposes that firms can and should use external as well as internal innovations/ideas. A popular example of open innovation has been open source software (OSS). The key issues facing organizational decision makers considering OSS strategies is, how does the firm create value for the customer while simultaneously extracting value for itself? However, the adoption of OSS as part of an open innovation strategy is a recent phenomenon and many unanswered questions remain. Taking the viewpoint of seven IS/IT decision makers in European firms, this paper reveals how decision makers considered aspects of value creation, capture, and networking in making decisions on adopting open source software. The findings reveal that while decision makers look to open innovation for value creation and capture, there is still a desire to remain self reliant, resulting in collaborative design (of external innovations) rather than collaborative decision making with value network partners in relation to how such innovations would help create and capture value within firms.
\end{abstract}

Keywords Open innovation, open source software, value creation, value capture, value network

Please use the following format when citing this chapter:

Morgan, L., and Finnegan, P., 2008, in IFIP International Federation for Information Processing, Volume 287, Open IT-Based Innovation: Moving Towards Cooperative IT Transfer and Knowledge Diffusion, eds. León, G., Bernardos, A., Casar, J., Kautz, K., and DeGross, J. (Boston: Springer), pp. 229-246. 


\section{INTRODUCTION AND RESEARCH MOTIVATION}

For most of the $20^{\text {th }}$ century, innovation happened inside the business and companies rarely looked outside for new ideas or inventions (Tapscott and Williams 2005). According to Chesbrough (2004), a paradigm shift is taking place in how companies commercialize knowledge; characterized as a move from closed innovation to open innovation. Closed innovation is a view that successful innovation needs control and that firms need to be strongly self-reliant because of uncertainty with quality, availability, and capability of others' ideas. Chesbrough (2004) proposes that with the open innovation paradigm, firms can and should use external as well as internal ideas and that internal ideas can be taken to market through external channels, outside a firm's current business, to generate value. According to Chesbrough (2006), ideal businesses resist the "not invented here" and "not sold here" syndromes in favor of open innovation. They search outside their own companies for the best ideas, seeking input from other companies, including competitors, as well as from customers, suppliers, and vendors. Most importantly, new products are not the only tangible manifestation of open innovation. Services and process transformation are equally important facets, whether it is to create enhanced customer support or to support internal business efficiencies (British Telecom 2006). Gassman and Enkel (2004) identify three core open innovation processes: (1) the outside-in process, where a company's innovativeness can increase through the integration of suppliers, customers, and external knowledge sourcing, (2) the inside-out process, where companies can earn profits by bringing ideas to market and transferring ideas to the outside environment, and (3) the coupled process where companies can combine the outside-in and inside-out processes by working in alliance with complimentary partners where give and take is vital for success. Gassman and Enkel found that while companies choose one primary process, they often integrate some elements of the other.

A popular example of open innovation is open source software, as exemplified by the Linux operating system and Apache server. A formal definition of OSS, published by the Open Source Initiative, establishes that software can be called open source if it and its source code can be freely modified and redistributed (see http://www.opensource.org). This phenomenon involves thousands of programmers contributing to large and small scale projects where the central organizing principle is that the software remains free of most constraints on copying and use common to proprietary materials (Benkler 2002). As Gassman and Enkel state, "this principal drives the evolutionary development and improvement of the software" (p. 2). Furthermore, companies interested in an OSS approach can decide on any of the three underlying open innovation processes mentioned above. For example, in the past, companies such as HP and Sun have used an outside-in process by donating research and development to the Mozilla open source project while exploiting the pooled R\&D and knowledge of all contributors (i.e., academics, user organizations, individual hobbyists, etc.) to facilitate the sale of related products. The result was that these firms maximized the returns of their innovation by concentrating on their own needs and then incorporating the shared browser technology into their own integrated systems (West and Gallagher 2006). Other companies like IBM have often used an inside-out approach as part of its OSS initiative that represented spinouts in the 1990s and, more recently, donated software patents to the OSS community (West and Gallagher 2006). In addition, the aforementioned companies have also integrated ele- 
ments of the coupled process by successfully cooperating with universities, research institutes, etc. in both exploiting and sharing information and knowledge.

According to Agerfalk et al. (2005), the open source movement has pragmatically shifted the center of gravity toward a more business-friendly and hybrid concept, and, in commercial settings, OSS is rapidly transforming into a viable alternative to proprietary software. Indeed this accommodation with the commercial mainstream may be a harbinger of an end to the current dominance of a proprietary, closed source software model (Fitzgerald 2006). However, despite research carried by West and Gallagher (2006) and by West (2007), the use of OSS as part of an open innovation strategy is such a recent phenomenon that many unanswered questions still persist. Furthermore, existing research is based on the experiences of U.S. firms. The shifting of focus from ownership to the concept of openness requires a reconsideration of the processes that underlie value creation and value capture, and thus necessitate consideration of the issue at the level of a business model (Chesbrough and Appleyard 2007), although the consideration of such issues using value chain analysis (Porter 1985), transaction cost economics (Williamson 1981), and the resource-based view of the firm (Barney 1991) may also prove useful. However, such approaches are based on ownership and control as the key levers in achieving strategic success. Consequently, all focus largely within the firm, or within the value chain in which the firm is embedded, and by doing so take no notice of the potential value of external resources that are not owned by the firm in question (Chesbrough and Appleyard 2007).

Chesbrough (2003) asserts that firms need a business model to profit from innovation as a successful business model may offer more value to the customer or completely replace the old way of doing things (see Magretta 2002). According to Osterwalder and Pigneur (2002, p. 2) a business model can be defined as

a description of the value a company offers to one or several segments of customers and the architecture of the firm and its network of partners for creating, marketing and delivering this value and relationship capital, in order to generate profitable and sustainable revenue streams.

For Osterwalder and Pigneur, a business model is "the missing link between strategy and business processes" (p. 3). West and Gallagher propose that the combination of shared production and low cost of OSS has resulted in firms reconsidering their proprietary business models and that the fundamental question for a firm's business model is, how does the firm create value for the customer while simultaneously extracting some of the value for itself? However, it has been found that the use of open source by firms generally begins in ways that does not disrupt their fundamental business model, or comes at a time when their existing business model is so threatened that they are forced to make radical changes (West and Gallagher 2006). In general, the comprehension of issues surrounding OSS business models appear inadequate. As Feller et al. (2006) found, much of the research in the area of OSS to date has instead focused on sociocultural and software engineering issues. While researchers such as Hecker (2000), Koenig (2004), Krishnamurthy (2005), and Onetti and Capobianco (2005) have undertaken much research to refine and elaborate OSS business models, revenue generation has been the main focus for most of this research, neglecting other aspects of the business model such as the value component. 
Prior research has identified three key elements of a business model: value creation, value capture, and a value network (Chesbrough 2006; Chesbrough and Rosenbloom 2002; Morris et al. 2005; Teece 18761 Shafer et al. 2005; West 2007). Open innovation explicitly incorporates the business model as the source of both value creation and value capture. However, Chesbrough (2006) argues that while open source shares the focus on value creation throughout the value chain, its proponents usually deny or downplay the importance of value capture. Value creation can be defined as a universal element of recent conceptions of a business model and entails identifying relevant customer segments, the value proposition for each, and how that business model will provide that value (West 2007). Value capture explains how a firm captures value from its value creation. Some of the key steps are to define a revenue model, ensuring the cost structure is consistent with the customer's perceived value and the portion that will be captured, and that firms establish durable external relationships with customers and third parties (West 2007). However, OSS has a lower formal appropriability than proprietary software because the source code is available for reuse and modification by competitors, complementors, and customers. It has been suggested that for firms utilizing OSS, "the business model depends on selling complementary goods or services to capture value, or leveraging tacit knowledge or other intangible sources of advantage over rivals" (West 2007, p. 179). In order to understand value creation and value capture in the context of OSS, Helander and Laine (2006) argue that value needs to be defined in nonmonetary as well as monetary terms. Open innovation also both enables and builds on interorganizational collaboration, often referred to as a value network (West and Gallagher 2006) or ecosystem (Adner 2006). Dahlander (2004) proposes that in addition to interorganizational relations, it is relations with users and developers that constitute the OSS community that are important for the firm.

With the exception of West and Gallagher (2006) and West (2007), academic research on value creation, value capture, and value networks in OS strategies appears to be rather sparse. Furthermore, literature articulating the central characteristics of OSS that enable or hinder value creation and value capture is quite limited. This paper attempts to address this gap by first investigating the circumstances that motivate European firms to embrace an open innovation strategy such as OSS. Second, it will identify the characteristics of OSS that enable or impede a firm's business model to create and capture value. The role of the value network in creating and capturing value will also be explored. The paper is organized as follows. It begins by discussing the research objective and research method. The findings are then presented. The paper concludes that there are many characteristics that have the potential to achieve value creation, value capture, and a value network. However, there also exist many characteristics that have the potential to impede value creation and value capture. In addition, OSS offers a major example of how open innovation can change a business since collaborating as part of a value network appears to be a crucial source of both value creation and value capture.

\section{RESEARCH OBJECTIVE AND METHOD}

The objective of this study is to (1) examine the circumstances that motivate decision makers in commercial firms to embrace an OSS strategy and (2) identify the charac- 
teristics of OSS that enable or hinder value creation, value capture, and a value network. Due to the relatively novel phenomena being examined and the scarcity of empirical work in the area, the study was categorized as exploratory. In such circumstances, Marshall and Rossman (1989) suggest that either a case study or field study research methodology can be used. The researchers decided that a field study would be appropriate as it would facilitate the collection of rich data from a larger number of organizations and would form the basis for more focused research at a later stage. A stratified sample was used to give diversity in the sample (see Patton 1990). Data collection was carried out using semi-structured interviewing in seven companies (see Table 1). Each interview lasted between 45 minutes and 2 hours. Content analysis was undertaken using coding techniques proposed by Strauss and Corbin (1990). This approach recognizes that social phenomena are complex, and seeks to develop theory systematically in an intimate relationship with the data. This form of analysis facilitates the development of substantive theory without prior hypotheses (Baskerville and Pries-Heje 2001) and can be utilized in the absence of, or in conjunction with, existing theory. In the initial phase, open coding was used to determine the main ideas in each transcript. These ideas were then grouped by significant headings to reveal categories and subcategories. The next step involved axial coding, which is the process of relating categories to their subcategories. As a list of codes began to emerge, the analysis moved to a higher or more abstract level, looking for a relationship between the codes. Once a relationship had been determined, the focus returned to the data to question the validity of these relationships.

Table 1. Companies Studied

\begin{tabular}{|l|l|l|l|}
\hline \multicolumn{1}{|c|}{ Name } & \multicolumn{1}{c|}{ Business } & \multicolumn{1}{c|}{ Extent of OSS Adoption } & Respondent \\
\hline $\begin{array}{l}\text { Eircom Group } \\
\text { PLC, Ireland }\end{array}$ & Telecommunications & $\begin{array}{l}\text { Some use of OS products in } \\
\text { technical support, e.g., JBoss } \\
\text { application server, MySQL, but } \\
\text { quite limited adoption }\end{array}$ & $\begin{array}{l}\text { Technical } \\
\text { Architecture } \\
\text { Manager }\end{array}$ \\
\hline $\begin{array}{l}\text { Nokia Research } \\
\text { Centre, Finland }\end{array}$ & $\begin{array}{l}\text { Mobile } \\
\text { Communications }\end{array}$ & $\begin{array}{l}\text { Extensive use in telecommuni- } \\
\text { cations infrastructure and } \\
\text { embedded applications }\end{array}$ & $\begin{array}{l}\text { Head of } \\
\text { Software } \\
\text { Technology }\end{array}$ \\
\hline $\begin{array}{l}\text { Phillips Medical } \\
\text { Systems, } \\
\text { Netherlands }\end{array}$ & $\begin{array}{l}\text { Supplier of medical } \\
\text { equipment and } \\
\text { devices }\end{array}$ & $\begin{array}{l}\text { Limited; involved in some OS } \\
\text { projects; hope to increase level } \\
\text { of adoption }\end{array}$ & $\begin{array}{l}\text { International } \\
\text { Project Leader }\end{array}$ \\
\hline $\begin{array}{l}\text { Sony Computer } \\
\text { Entertainment } \\
\text { Europe, UK }\end{array}$ & $\begin{array}{l}\text { Manufacturers and } \\
\text { distributors of } \\
\text { entertainment } \\
\text { systems }\end{array}$ & $\begin{array}{l}\text { Extensive use in servers, con- } \\
\text { sumer products, etc.; increasing } \\
\text { levels of adoption }\end{array}$ & $\begin{array}{l}\text { Technical } \\
\text { Specialist }\end{array}$ \\
\hline $\begin{array}{l}\text { St. Galler } \\
\text { Tagblatt AG, } \\
\text { Switzerland }\end{array}$ & Media & $\begin{array}{l}\text { Extensive, entire SAP software } \\
\text { environment }\end{array}$ & $\begin{array}{l}\text { Chief } \\
\text { Information } \\
\text { Officer }\end{array}$ \\
\hline Supertramp, UK & Manufacturing & Extensive (100\% open source) & $\begin{array}{l}\text { Technical } \\
\text { Director }\end{array}$ \\
\hline $\begin{array}{l}\text { Vodafone, } \\
\text { Spain }\end{array}$ & $\begin{array}{l}\text { Mobile } \\
\text { Communications }\end{array}$ & $\begin{array}{l}\text { None; collaborating with others } \\
\text { to create Linux platform for } \\
\text { mobiles }\end{array}$ & $\begin{array}{l}\text { R\&D Engineer } \\
\text { Head of R\&D }\end{array}$ \\
\hline
\end{tabular}




\section{FINDINGS}

\subsection{What Circumstances Motivate Decision Makers in Commercial Organizations to Embrace an OSS Strategy?}

The study revealed that the circumstances that motivated decision makers to embrace or to consider embracing an OSS strategy varied. In the case of Supertramp, the technical director explained that prior to OSS adoption, booming sales meant their proprietary-based IT systems were becoming overloaded and customer service was suffering as a result. He pointed out that "the company's problem was that its market share was growing and the business was growing so rapidly...the systems that we were using just were not going to scale and the scalability was what was required." Microsoft, at the time, were bringing out a volume licensing program, which meant that the company was starting to feel the push to this upgrade path. As the technical director further explained, "We were looking really at quite a significant budget, something in the region of about $£ 15,000$. This was quite an expense but we were also struggling with scalability and reliability issues and they were probably contracting more value from the business than just facing the licensing costs." This finding tends to support those of West and Gallagher (2006) who proposed that the use of OSS by firms comes at a time when their existing business model is so threatened that they are forced then to make radical changes. This was one of the things that drove the decision to adopt OSS in the company because they knew they "could go from 10 to 40 users without any more licensing costs, proprietary software costs and that the system would more than likely deliver it" (Technical Manager, Supertramp). Similar to Supertramp's case, the CIO at St. Galler Tagblatt explained that the company was attracted to the enormous cost saving potential of OSS. Previous to OSS adoption, the company found the cost of software licensing and major hardware and software upgrades quite challenging. As part of an IT strategy in 2003, the company decided to migrate the existing SAP software environment and third-party system maintenance applications to Linux while implementing MaxDB as a costeffective alternative to their previous database system. As the CIO in the company explained, "in this strategy we declared that we wanted to use Linux whenever possible and Windows when we had to. And we wanted the cheaper Unix but with the stability of Unix. And so SAP is running out of Linux since 2004 without any problems."

For SCEE, the technical specialist explained that open source software was not at the core of their business plan or activities (which revolve around developing and releasing Playstations and Playstation games, and the sale of software). Rather, the use of OSS in products arose out of consumer demand for the product (thousands of requests from open-source programmers who believed that this product could make a significant contribution). This finding is in line with Chesbrough's (2006) suggestion that one business model that makes good business sense is to be very open with technologies that are not inputs to the core activities of the firm but still are complementary. For SCEE, it can be said that customer perceptions were the value drivers for this company, thus one of their reasons for deciding to embrace OSS. As this technical specialist revealed, "They wanted this product, they wanted to be able to have Linux running on the machine and to be able to run OSS." However, it can also be suggested that the use of OSS by this firm began in such a way that it would not interfere with their core business model, 
thus supporting findings from West and Gallagher. This technical specialist further explained that the Linux kit was not really made as a significant revenue source for the firm, but rather "it was made with a sort of business plan that we would break even on it. What it would do is give people a chance to get familiar with our platform from a development point of view so that people who go into the industry to make PS2 software do a better job because they have had the chance, with little cost to themselves, to get familiar with our hardware. So it was more of an intellectual game than a financial one."

According to the head of Software and Technology at Nokia Research Centre, there are two major efforts where the company has embraced OSS. One concerns the telecommunications infrastructure and products where Linux is used as one of the primary platforms and the other is Linux embedded applications. The head of Software and Technology in this company pointed out that one of the main reasons for embracing OSS was top management's desire to learn more about the software (i.e., where it could be used and how). Another reason was that the company favored components that were developed by active communities and used by many. The project leader at Philips Medical Systems also revealed that while the company has limited adoption of OSS at present, it is inevitable that they will have OSS in their products in a few years because he viewed this as the only way to get all of the software that the company needs. He further explained that pulling open source tools in the imaging systems environment would be useful because the company could use them to provide code for more platforms, reducing the risk of lock-in. Presently there are some bottom-up initiatives underway and the company is currently looking at the business values and problems of introducing OSS. For Vodafone, the R\&D engineer explained that while they have not yet adopted OSS, they are interested in it and see it as a new way of collaboration that will allow them to do more things from a technological point of view (e.g., develop a new operating system for mobile phones). The R\&D department in this company has already begun projects in open source and they have established contact with members of the open source community.

In contrast to the above, the technical architecture manager at Eircom explained that there was no formal policy in the company around OSS adoption and that it "crept in by osmosis." This manager felt that OSS was not a viable business approach per se and viewed it only as a development model. As he explained, "It's not a question of OS versus proprietary. We want to introduce better quality software to meet our needs. We wouldn't really discriminate on the development model used and that's all OSS is in our books, a development model that produces generally very high quality software." $\mathrm{He}$ further explained that "you can stand over a proprietary solution, by and large, because you can see how well the company is funded and how much they're spending on R\&D and where they are bringing the product to and why, what's driving them, and you can see their profitability and so on. And you can understand that that's a natural business model that we're all aware of. You can't see that in a lot of open source products, so you don't know where it's going to end up."

\subsection{Value Creation}

The study found that there were many characteristics of OSS that facilitated value creation for the companies. For Supertramp, the business processes were the value 
drivers and, thus, the focus on creating value was to improve the efficiencies of those business processes. Implementing OSS greatly enhanced the efficiency of their business processes, which in turn dramatically improved productivity and customer service. The lower costs associated with OSS were seen as very beneficial in this case. The technical director in the company explained that one of the advantages of implementing OSS was the ability "to utilize the flexibility of OSS and make it match the business process. And the low cost of it has meant that we could spend more of our budget on analyzing the business model in the first place." He further added that if the company had continued using proprietary systems, this would have resulted in more hardware and software upgrades, causing their investment in staff and staff capability to be significantly less than it is today. Similarly, the CIO at St. Galler Tagblatt also revealed that the total cost of ownership for the company is dramatically lower than that of their previous proprietary Unix environment and calculated savings of $€ 340,000$ a year as a result of moving to Linux.

According to West (2007) customers expect a richer whole product solution (e.g. , integration, customization, and support). One mechanism for creating some value is the use of complementary assets (see Teece 1986). The technical specialist at SCEE pointed out that the lower costs associated with OSS facilitated the creation of an infrastructure that encourages participation and collaboration between the company and their customers. The company provides support websites (all running on OS based software) that give support to their customers for PS2, PSP, and PS3. As the technical specialist explained, "The whole support infrastructure that we have for developers working on games for those machines is based around our support infrastructure, our websites, our newsgroups, instant messaging services, and those are all running on OS based software." She further explained that the Linux for PS3 provides an option for third-party system software to be installed on the PS3 system instead of the system provided by SCEE, thus leveraging its value creation to customers. The head of Software and Technology at Nokia Research Centre also pointed out that the company finds it beneficial to use OSS in some of their consumer products because, in addition to saving time and money, it allows the company to shape their products according to market needs. The use of OSS in their product creates value to the customers as it offers them upgraded software, enhanced features, and improved performance. For some of its products, Nokia releases the code to the open source community, enabling both knowledge sharing and collaboration, in addition to creating value that is seen as beneficial to the community. In this way, the company not only counts on third-party developers adopting them widely, but also innovating on the core technology. In addition, the head of Software and Technology at Nokia Research Centre considered the low cost of OSS extremely valuable as it allowed the company to share expenses with other companies with whom they had made joint ventures, thus enabling more value creation in the company.

The quality, reliability, security, and performance of OSS were also perceived by all of the companies as particularly important characteristics in facilitating value creation. For example, respondents pointed out that the quality of developers, the enhanced quality from peer reviews, and the quality of OSS tools and software were superb, hence enabling their respective companies to create more value. In terms of the quality of OSS packages, the technical specialist at SCEE explained that they had many examples where they were able to pick up something that was an already established and proven tool and a serious contender with other licensed software alternatives in the market. This in turn 
gave the company the ability to get an entire platform of functionality together by using software that had "been reviewed and used in anger by other people" (Technical Specialist, SCEE). Similarly, the technical director at Supertramp found the quality of support, available knowledge, and willingness of the open source community quite remarkable and pointed out that he did not see that level of support availability from proprietary companies. However, while the technical architecture of Eircom viewed quality as one of the benefits of OSS, he also stated that this could only be applied to top-tier, mature, open source products like Linux, Apache, and MySQL. Similarly, the head of Software and Technology at the Nokia Research Centre agreed that some open source products like Linux have established themselves over the years but many are not as mature.

With regard to the reliability of OSS, the technical manager at Supertramp explained that "when they brought their enterprise resource planning system server down, which was running RedHat Linux, for a hardware upgrade, it had 1,011 days of time on it as it never had to be rebooted." Also in relation to the stability and security of OSS, it was found that in comparison to proprietary packages, there was no need to install anti-virus software on everything as there was no need for it. As the head of Software and Technology at Nokia Research Centre explained, "In terms of security, there are advantages because there are less viruses and worms and whatnot around compared to Windows." The technical specialist at SCEE also pointed out that "we know people are able to see how the software works, what the back end is like and really we are quite big subscribers to not going for security through obscurity but security through proper methods." In terms of performance, the technical director for Supertramp explained that by switching from Windows to Samba, the performance capacity over the networks for file sharing greatly improved. He also found that their Linux server could handle 25 or 26 clients in comparison to 14 or 15 on Windows. Similarly, the CIO of St. Galler Tagblatt discovered that by implementing OSS, the batch jobs in their SAP environment were three to nine times faster than with Unix.

However, it became apparent that there are many characteristics of OSS that have the potential to impede value creation. For example, it was found that one of the biggest obstacles to value creation was the lack of ownership issue. One likes to know that if there is a problem, they can pick up the phone and this problem can be analyzed and fixed. For example, the project leader at Philips Medical systems revealed that "if our developers cannot find the source of the problem, then it may take longer than they expected. The history of OSS tells differently but formally there is no one to go to... who is responsible for what is less clear in an open source environment." However, contrary to this, the technical director at Supertramp believed that "that's a complete façade because if you look at any end user license agreement, the first thing that they do in an license agreement, proprietary or open source, is waive all responsibility and warranty. So I think that that's just the marketing spiel that we see in breeding fear, uncertainty and doubt." The majority of the companies considered the lack of user support to be a real impediment to creating value. Some of the companies have teams of talented technicians that can cover the support risk internally. However, this is not always an option for many of the smaller organizations or very large organizations that have problems finding the right staff and competencies required to carry out this support. The technical manager at Eircom explained that, to solve the support problem, "We aligned ourselves with a third party support supplier....In other words, we have shouldered the risk on to them. What that gives us though, in fairness, is expert support services from a competent 
supplier who is active in the open source community and familiar with those individual products and is in fact working with them on a daily basis in the context of their own product development."

Other issues with the potential to hinder value creation included compatibility issues and poor documentation. For example, the technical specialist at SCEE mentioned that compatibility of OSS with current tasks of developers was a concern as they sometimes were uncomfortable and unhappy with having to use OS based operating systems packages. The technical architecture manager at Eircom also pointed out that there are often issues with the compatibility of OSS products with the current technology in the company. He pointed out that the company was like a brass clock and explained, "It has to run smoothly and it has to run in a predictable fashion. When you open up the brass clock, everything inside it must be compatible...they must all be of an industrial strength. Also for a clock to be efficient, it needs to have the right number of parts in it....So when you look at the likes of open source, because you can acquire for free or very close to it...select a product and then download it and install it and so on. The issue that arises in here, for example, is that we end up with a lot of moving parts. More than we need and overlapping parts, competing parts, not the place to be." In terms of poor documentation, the IT specialist at SCEE explained that, "If you try and find a software package to access database or templating layer or whatever you are looking for, you'll find a myriad of solutions that will claim to meet your needs and some of them will have died in development some time ago."

\subsection{Value Capture}

Various attributes of OSS also enabled the companies to capture value in different ways. For example, the technical manager in Supertramp explained that by migrating to OSS, in addition to dramatic cost savings, the company "didn't have any data corruption and all of a sudden we had all of our data in one place, both financial and customer relationship management. It really transformed...the business process." Because the migration to OSS was so successful, the company decided to create a spinout company (i.e., the process of reaching external markets through external business ventures, with the explicit intention of providing reliable and effective IT solutions to other businesses). According to West (2007), firms have opportunities to release more value from their technologies by situating them outside the firm, but at the same time maintaining corporate involvement. Focusing on an inside-out process by transferring ideas outside the company's boundaries had clear advantages for Supertramp in terms of both value creation and value capture as they were able to leverage their experience with OSS to meet a new customer requirement, thus opening up a whole new revenue stream. OSS had already proven itself in the company and many of its staff members were experienced technically with the software, thus reducing the risk of failure in this new venture.

For SCEE, the value capture in utilizing OSS was "the fact that we can do some of the research using existing OSS tools, create some of the products based on OSS systems, and run out support sites using OSS is an extra saving that we would lose otherwise" (Technical Specialist, SCEE). By using OSS, the company could better afford an inhouse team of website developers who were able to create the custom development that the company needed to increase the value of their services to developers. Therefore, the 
quality of the product was better and produced in less time and with fewer resources than it would otherwise need. For this company, using OSS had a direct effect on their ability to acquire and retain a new customer segment, in addition to managing ongoing relationships with them. This technical manager also explained that the company captures superior technical knowledge and pointed out that "we have been able to find staff to bring on to the team who have had experience in some of the packages that we are using, which is a great benefit." She further explained that the open platform created by the company for its PS3 product may lead to some interesting opportunities as well as aiding the technical development of people who join their industry in the future. For Nokia, the head of Software and Technology explained that the company captures value as the use of OSS in their products saves time and increases the profits of sale through money saved on software components. Working as part of a community also provides the company with access to code and engineers outside of their own development team. It is evident that both SCEE and Nokia captured value by focusing on an outside-in process where external knowledge gained from customers and the OSS community was integrated in their product development.

The escape from vendor lock-in was also seen as an important trait of OSS that enables value capture. The head of R\&D at Vodafone explained that this would be one of the reasons for embracing an open innovation strategy like OSS because, he pointed out, "Every time we use a piece of software from another company, for every time that software is used, we have to pay them a certain amount of money. That's killing our margin." The technical director at Supertramp was also pleased with the sense of control in being able to change things as and when they wanted to without being forced to do so. As he explained, "One of the problems that you come across with a proprietary infrastructure is that your proprietary vendors tend to be putting their software and their systems on a release cycle and they tend to want to push you into continuing with updates and moving forward on a treadmill that suits them as the supplier." The flexibility allowed by OS licences was viewed as quite significant in capturing value for the majority of the companies because it had a dramatic impact on reducing capital expenditure, in particular for the companies that had adopted OSS. The fact that OSS encourages innovation was also viewed as advantageous in capturing value as access to the source code produces more ideas and creates opportunities for more innovation and creativity. As the technical director of Supertramp explained, "It's very straightforward to be innovative when you have access to all the code...the ability to be able to think about what can be done in the business system...now I can actually go deep into the core of my systems and I can make the systems do that because I can write into it. And that means we do innovate." Again, all of the companies found the flexibility of use associated with OSS extremely beneficial in terms of value capture, facilitating changes and customization, allowing for mixing and matching of components used, facilitating experimentation, and permitting freedom of choice in new server hardware.

However, there were also some characteristics of OSS that were viewed as impediments to value capture. For example, three of the companies mentioned that the idea of giving away the source code might be perceived by others in their respective companies as a hurdle to capturing value. As the head of R\&D at Vodafone pointed out, "You know if we were to share - it's one asset for killing an idea....Somebody will have that great idea what that new thing is...that somebody could be inside Vodafone. Basically we should protect that and we cannot give that away." According to the project leader at 
Philips Medical Systems, there are still many people in the company nervous about this issue but added that there are certain parts that can be given away without any problem. Difficulties in finding the right staff and developing the competencies to work with OSS were also seen as potential obstacles to capturing value. For example, the head of Software and Technology at Nokia revealed that the company finds it difficult to locate top quality staff and competencies to work with OSS, particularly where the company is attempting to embed OSS into their products and technologies. He added that, for application development, there is no problem finding staff, but for the type of work that the Nokia Research Centre is carrying out, the staff need to be well versed in OSS. Likewise, the head of R\&D at Vodafone explained that the ability to create and develop new competencies requires a different way of thinking because OSS will be new to them. Another impediment to capturing value was the lack of roadmaps associated with an OSS product and its life cycle. For example, the technical infrastructure manager at Eircom believed that it was difficult to see any strategic direction for the vast majority of the products that are available in OSS. He also added that most OSS products were built to either displace an existing product or to solve a particular problem and, therefore, most of them had no strategic intent. This, he pointed out, could cause problems because as a team moves on to greater and more challenging technical projects, the product itself may not move one iota from where it currently is.

\subsection{Value Network}

The majority of the companies have established quite successful value networks. enabling both value creation and value capture. These networks have been extremely beneficial in terms of the high levels of knowledge and know-how being communicated and the open, transparent process in which the interaction takes place. Further, companies like Nokia Research Centre, SCEE, and Supertramp have integrated elements of the coupling process (i.e., combination of an outside-in and inside-out process), which has been a key success factor for them. For example, the head of Software and Technology at Nokia acknowledged the value in creating OSS in collaboration with others. As he explained, "We and other companies have done quite a lot in trying to make joint ventures or joint exercises around open source.....we made a joint effort to enhance Linux with some features that are important for the telecom infrastructure." The company also works with communities to enhance components and develop them further. One such example is the Eclipse Foundation, an open source community whose membership includes IBM, Hewlett Packard, and Intel. This consortium is focused on creating an ecosystem that enhances, promotes, and cultivates an extensible development platform with complementary products, services, and capabilities. Nokia plans to use the Eclipse tools platform widely in its tools portfolio and is comfortable cooperating with some of their competitors to further develop and drive adoption of this shared technology.

SCEE has built up quite a significant customer base of its Linux for Playstation products and in this way benefits from extensive suggestions and feedback, which increases the value of their product. As the technical specialist explained, "We get lots of feature requests that come in and a lot of quite significant add-ons that they want us to provide." This technical specialist also explained that they had successfully collaborated with another company to produce their Linux for PS3 product. The Technical 
Manager at Supertramp also outlined how its spinout company has collaborated with other companies to deliver state of the art technology systems. Similarly, Philips Medical Systems described how they have a number of collaborative projects with other firms and academic institutions. Presently, the company is one of 19 partners, including Nokia and Siemens, in the Eureka ITEA programs, which deals with OSS in a distributed development setting and is looking at business processes as well as technical processes. The R\&D engineer at Vodafone also felt that "OSS is a new way of collaboration between people." The company has successfully collaborated with the Spanish government, who has funded them in their effort to develop a Linux mobile platform with other companies that include Motorola and Samsung.

\section{CONCLUSION}

We have examined the factors that affected the decision to adopt OSS as part of an open innovation strategy in seven European firms (see Table 2). This examination used a business model framework as it represents the architectural/logical design that connects a firm's strategy with its operational activities. Consequently, we consider it a useful lens to examine how decision makers reconcile strategic directions on open innovation with the operational aspects of adopting a particular open innovation strategy such as OSS. Consistent with findings from West and Gallagher (2006), it was obvious from the study that the use of open source by several of the firms began in a way that would not disrupt their core business model, as was the case with Sony Computer Entertainment Europe, or came at a time when their existing business model was under threat, forcing radical changes, as with Supertramp. However, it was apparent that the decision to embrace open source software proved very beneficial for the companies in which it has been implemented.

Table 2. Circumstances that Motivated Firms to Embrace an OSS Strategy

\begin{tabular}{|l|l|}
\hline \multicolumn{1}{|c|}{ Factor } & \multicolumn{1}{c|}{ Description } \\
\hline Low Cost & $\begin{array}{l}\text { Attracted by cost saving potential of OSS in relation to licensing and } \\
\text { hardware/software upgrades }\end{array}$ \\
\hline Scalability/Quality & $\begin{array}{l}\text { Embraced OSS because of scalability and reliability issues with } \\
\text { proprietary based IT systems }\end{array}$ \\
\hline Staff Development & Could invest more resources in staff training and development \\
\hline $\begin{array}{l}\text { Consumer } \\
\text { Demand }\end{array}$ & Customers wanted OSS products running on their machines \\
\hline $\begin{array}{l}\text { Desire of Top } \\
\text { Management }\end{array}$ & $\begin{array}{l}\text { Top management wanted to learn more about software (i.e., where it } \\
\text { could be used and how) }\end{array}$ \\
\hline OSS Components & Preference for components developed by active communities \\
\hline $\begin{array}{l}\text { Reduced Risk of } \\
\text { Lock-in }\end{array}$ & $\begin{array}{l}\text { Could use open source tools to provide code for more platforms, thus } \\
\text { reducing the risk of lock-in }\end{array}$ \\
\hline $\begin{array}{l}\text { New way of } \\
\text { collaboration }\end{array}$ & $\begin{array}{l}\text { OSS is viewed as a new way of collaboration with other companies, } \\
\text { OSS community, government, etc. }\end{array}$ \\
\hline
\end{tabular}


Additionally, it was found that there are many characteristics of OSS that enable firms' business models to create and capture value. For example, some defining characteristics that help achieve value creation include low cost, quality, and performance, while attributes such as escape from vendor lock-in, encouraging innovation, and flexibility of use enable companies to capture value. It was also found that firms adopt or take interest in open innovation strategies like OSS in order to facilitate and enhance their capacity to create and capture value to the customer (see Table 3). For example, Supertramp utilized the software to improve their business processes, thus creating value in the form of improved customer support. This finding also contributes to previous studies on OSS in the context of open innovation that generally tend to be predisposed toward product innovations and ignore innovations to improve processes or business efficiencies.

For several of the companies, OSS was also a way of entering markets and acquiring new customers. Incorporating OSS into their products created value to the customers who believed the software could make a distinctive contribution. The value creation included delivering enhanced products and improved performance, in addition to providing complementary assets to customers (e.g., support infrastructure). Deciding on an outside-in process has proved successful for companies like SCEE and Nokia Research

\section{Table 3. How Companies Create and Capture Value}

\begin{tabular}{|c|c|c|}
\hline & $\begin{array}{l}\text { For Company } \\
\text { - } \quad \begin{array}{l}\text { Enhanced efficiency of business } \\
\text { processes leading to improved quality } \\
\text { and productivity }\end{array} \\
\text { - } \quad \begin{array}{l}\text { Reduced susceptibility to viruses, etc. } \\
\text { Ability to acquire new customer }\end{array} \\
\text { segments/meet customer requirements } \\
\text { Allows more investment in staff } \\
\text { development/training } \\
\text { - Lower TCO } \\
\text { Enables knowledge sharing/collaboration } \\
\text { with communities, customers, etc. } \\
\text { Facilitates joint ventures with other } \\
\text { companies }\end{array}$ & $\begin{array}{ll}\text { For Customer } \\
\text { - } & \text { Improved customer } \\
\text { - } & \text { service/satisfaction } \\
& \text { Enhanced software, upgraded } \\
& \text { features and improved } \\
\text { performance } \\
\text { - Provision of complementary } \\
\text { services (e.g., support } \\
\text { infrastructure, third-party } \\
\text { system } \\
\text { Increased } \\
\text { participation/collaboration with } \\
\text { company }\end{array}$ \\
\hline & \multicolumn{2}{|c|}{$\begin{array}{ll}\text { - } & \text { Creation of spin-out company } \\
\text { - } & \text { Captures superior technical knowledge } \\
\text { - } & \text { Saves time, reduces capital expenditure and increases profits } \\
\text { - } & \text { Access to code and engineers creates more opportunities for } \\
\text { innovation/creativity } \\
\text { - } \quad \text { Escape from vendor lock-in } \\
\text { Flexibility of use permits freedom of choice, customization, experimentation } \\
\text { etc. }\end{array}$} \\
\hline 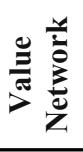 & \multicolumn{2}{|c|}{$\begin{array}{ll}\text { - } & \text { Cooperation/collaboration with communities (e.g., Eclipse) } \\
\text { - } & \text { Joint ventures with companies } \\
\text { - Collaboration with customers, government, academic institutions and other } \\
\text { companies }\end{array}$} \\
\hline
\end{tabular}


Table 4. Impediments to Value Creation and Value Capture

\begin{tabular}{|l|l|l|l|}
\hline $\begin{array}{l}\text { Impediments } \\
\text { to Value } \\
\text { Creation }\end{array}$ & \multicolumn{1}{|c|}{ Description } & $\begin{array}{l}\text { Impediments to } \\
\text { Value Capture }\end{array}$ & \multicolumn{1}{|c|}{ Description } \\
\hline $\begin{array}{l}\text { Lack of } \\
\text { ownership }\end{array}$ & $\begin{array}{l}\text { Inability to hold someone } \\
\text { responsible or accountable } \\
\text { for problems }\end{array}$ & $\begin{array}{l}\text { Finding staff/ } \\
\text { competencies }\end{array}$ & $\begin{array}{l}\text { Often difficult to find top } \\
\text { quality staff and develop } \\
\text { competencies to work } \\
\text { with OSS }\end{array}$ \\
\hline $\begin{array}{l}\text { Lack of } \\
\text { support }\end{array}$ & $\begin{array}{l}\text { No safety net as there is no } \\
\text { support or company to back } \\
\text { it up. Companies may need } \\
\text { to seek out available skills } \\
\text { and services which can be } \\
\text { difficult and costly }\end{array}$ & $\begin{array}{l}\text { Lack of road- } \\
\text { maps with OSS } \\
\text { products }\end{array}$ & $\begin{array}{l}\text { Makes it difficult for } \\
\text { companies to see any } \\
\text { strategic direction with } \\
\text { OSS }\end{array}$ \\
\hline $\begin{array}{l}\text { Poor } \\
\text { documentation }\end{array}$ & $\begin{array}{l}\text { Documentation outdated or } \\
\text { may have died in } \\
\text { development }\end{array}$ & $\begin{array}{l}\text { Access to the } \\
\text { source code }\end{array}$ & $\begin{array}{l}\text { Some discomfort with } \\
\text { releasing source code for } \\
\text { products }\end{array}$ \\
\hline $\begin{array}{l}\text { Compatibility } \\
\text { Issues }\end{array}$ & $\begin{array}{l}\text { Compatibility problems with } \\
\text { current technology, skills } \\
\text { and tasks }\end{array}$ & & \\
\hline
\end{tabular}

Centre in terms of value capture. As well as saving time and money, nonmonetary gains such as the technical knowledge captured were s viewed as extremely beneficial for these companies. In addition, companies like Supertramp that choose an inside-out process as part of their open innovation strategy captured value through the creation of a spinout company. It was also quite obvious in the study that OSS is a compelling example of how companies can manage a value network to create and combine internal and external innovations. In this case, many of the companies have integrated elements of a coupled process. For example, companies like Nokia Research Centre and SCEE acknowledged the value in collaborating with other companies and OSS communities and felt there were many opportunities to be gained from a value network in terms of value creation and capture. Working as part of a value network enabled several of the companies to capture value in the form of competencies and tacit knowledge that in turn created superior value for the customer. However, impediments, such as those summarized in Table 4, have the potential to hinder both value creation and capture.

In conclusion, it is evident that the decision to embrace an open innovation strategy such as OSS is most highly influenced by the potential to create and capture value within the firm. It is also apparent that the issue of external collaboration with value network members is critical to creating and capturing value with an open innovation strategy. Nevertheless, it appears that value network collaboration centers on collaborative design rather than collaborative decision making on open innovation initiatives. This suggests that while firms seek to embrace open innovation strategies, they remain strongly influenced by the desire to remain self reliant, a characteristic of the closed innovation paradigm. Finally, this study has contributed to understanding decision making on the adoption of open innovation strategies by (1) examining the circumstances that motivate decision makers to embrace an OSS strategy, (2) investigating the characteristics of OSS 
that enable or hinder value creation, value capture, and a value network, (3) revealing the various ways in which value is both created and captured, and (4) highlighting the importance of collaborating as part of a value network. However, the findings reported here are based on a small sample of firms so it remains to be seen how they would replicate over a more wide-ranging sample in other European countries. In addition, the study did not take into consideration variables such as organizational size, structure, and culture. Therefore, the area would benefit from further research.

\section{Acknowledgments}

This work is supported by LERO - the Irish Software Engineering Research Center, the European Commission through the FP6 project OPAALS (project no. 034824), and the Irish Research Council for the Humanities and Social Sciences (IRCHSS).

\section{References}

Adner, R. 2006. "Match Your Innovation Strategy to Your Innovation Ecosystem," Harvard Business Review (84:4), pp. 98-107.

Agerfalk, P. J., Deverell, A., Fitzgerald, B., and Morgan, L. 2005. "Assessing the Role of Open Source Software in the European Secondary Software Sector: A Voice from Industry," Proceedings of the First International Conference on Open Source Systems, Genova, Italy, July 11-15, pp. 82-87.

Barney, J. B. 1991. "Firm Resources and Sustained Competitive Advantage," Journal of Management (17), pp. 99-120.

Baskerville, R., and Pres-Heje, J. 2001. "Racing the E-Bomb: How the Internet is Redefining Information Systems Development Methodology," in Realigning Research and Practice in Information Systems Development: The Social and Organizational Perspective, N. L. Russo, B. Fitzgerald, and J. I. DeGross (eds.), Boston: Kluwer Academic Publishers, pp. 49-68.

Benkler, Y. 2002. "Coase's Penguin, or, Linux and The Nature of the Firm," Yale Law Journal (112:3), pp. 369-446.

British Telecom. 2006. "Embracing Open Innovation: A New Approach to Creating Sustainable Value," White Paper (available from www.btglobalservices.com).

Chesbrough, H. 2003. Open Innovation: The New Imperative for Creating and Profiting from Technology, Boston: Harvard Business School Press.

Chesbrough, H. 2004. "Managing Open Innovation," Research \& Technology Management (47:1), pp. 23-26.

Chesbrough, H. 2006. Open Business Models: How to Thrive in the New Innovation Landscape, Boston: Harvard Business School Press.

Chesbrough, H., and Appleyard, M. 2007. "Open Innovation and Strategy," California Management Review (50:1), pp. 57-76.

Chesbrough, H., and Rosenbloom, R. S. 2002. "The Role of the Business Model in Capturing Value from Innovation: Evidence from Xerox Corporation's Technology Spin-Off Companies," Industrial and Corporate Change (11:3), pp. 529-555.

Chesbrough, H., Vanhaverbeke, W., and West, J. 2006. Open Innovation: Researching a New Paradigm, New York: Oxford University Press.

Dahlander, L. 2004. "Appropriating Returns from Open Innovation Processes: A Multiple Case Study of Small Firms in Open Source Software," unpublished paper, Chalmers University of Technology, Gothenburg, Sweden (http://opensource.mit.edu/papers/ dahlander.pdf). 
Feller, J., Finnegan, P., Kelly, D., and MacNamara, M. "Developing Open Source Software: A Community-Based Analysis of Research," in Social Inclusion: Societal and Organizational Implications for Information Systems, E. M. Trauth, D. Howcroft, T. Butler, B. Fitzgerald, and J. I. DeGross (eds.), Boston: Springer, pp. 261-278.

Fitzgerald, B. "The Transformation of Open Source Software," MIS Quarterly (30:3), pp. 587-598.

Gassman, O., and Enkel, E. 2004. "Towards a Theory of Open Innovation: Three Core Process Archetypes," in Proceedings of the R\&D Management Conference, Lisbon, Portugal, July 6-9 (http://www.alexandria.unisg.ch/Publikationen/274).

Hecker, F. 2000. "Setting Up Shop: The Business of Open Source Software," unpublished paper (online at http://www.hecker.org/writings/setting-up-shop.html).

Helander, N., and Martin-Vahvanen, H. 2006. "Multidisciplinary Views to Open Source Research," eBRC Research Reports 33, Tampere University of Technology and University of Tampere (available from http://www.ebrc.info).

Koenig, J. 2006. "Seven Open Source Business Strategies for Competitive Advantage," IT Manager's Journal, March 14 (http://www.riseforth.com/pdfs/Seven-Open-Source-BusinessStrategies-JCK.pdf).

Krishnamurthy, S. 2005. "An Analysis of Open Source Business Models," in Perspectives on Free and Open Source Software, in J., Feller, B., Fitzgerald, S. Hissam, and K. Lakhani (eds.), Cambridge, MA: MIT Press, pp. 279-296.

Marshall, C., and Rossman, G. 1989. Designing Qualitative Research, Newbury Park, CA: Sage Publications.

Magretta, J. 2002. "Why Business Models Matter," Harvard Business Review (80:5), pp. 86-92.

Morris, M., Schindehutte, M., and Allen, J. 2005. "The Entrepreneur's Business Model: Toward a Unified Perspective," Journal of Business Research (58:6), pp. 726-735.

Onetti, A., and Capobianco, F. 2005. "Open Source and Business Model Innovation. The Funambol Case," in Proceedings of the First International Conference on Open Source Systems, Genova, Italy, July 11-15, pp. 224-227.

Osterwalder A., and Pigneur 2002. Y. "An e-Business Model Ontology for Modeling eBusiness," in Proceedings of the $15^{\text {th }}$ Bled Electronic Commerce Conference, Bled, Slovenia, June 17-19 (http://www.hec.unil.ch/yp/Pub/02-Bled.pdf).

Patton, M. Q. 1990. Qualitative Evaluation and Research Methods, Newbury Park, CA: Sage Publications.

Porter, M. E. 1985. Competitive Advantage, New York: The Free Press.

Shafer, S. M., Smith, J. H., and Linder, J. C. 2005. "The Power of Business Models," Business Horizons (48), pp. 199-207.

Strauss, A., and Corbin, J. 1990. Basics of Qualitative Research: Grounded Theory Procedures and Techniques, Newbury Park, CA: Sage Publications.

Tapscott, D., and Williams, A. 2005. "Realizing the Power of Innovation Webs," Optimizemag.com, December (http://www.cioindex.com/nm/articlefiles/2776-Optimize_ InnovationWebs.pdf).

Teece, D. J. 1986. "Profiting from Technological Innovation: Implications for Integration, Collaboration, Licensing and Public Policy," Research Policy (15:6), pp. 285-305.

Williamson, O. E. 1981. "The Modern Corporation: Origins, Evolution, Attributes," Journal of Economic Literature (19:4), pp. 1537-1568.

West, J. 2007. "Value Capture and Value Networks in Open Source Vendor Strategies," in Proceedings of the $40^{\text {th }}$ Annual Hawaii International Conference on System Sciences, Los Alamitos, CA: IEEE Computer Society Press.

West, J., and Gallagher, S. 2006. "Challenges of Open Innovation: The Paradox of Firm Investment in Open-Source Software," R\&D Management (36:3), pp. 319-331. 


\section{About the Authors}

Lorraine Morgan is a project manager at the University of Limerick, Ireland, where she has worked on several research projects on open source software. She is currently pursuing a Ph.D. in Management Information Systems at University College Cork, Ireland. Her research interests include open source software business models, open innovation, and open source software adoption. Lorraine can be reached at lorraine.morgan@ul.ie.

Patrick Finnegan holds a Ph.D. from the University of Warwick, England, and is currently a Statutory Lecturer in Management Information Systems at University College Cork, Ireland. His research interests include electronic business and IS strategy. He research appears in various journals and conference proceedings including Information Systems Research, The Information Systems Journal, The Journal of Information Technology, The International Journal of Electronic Commerce, Information Technology \& People, Database, Electronic Markets, The European Conference on Information Systems, and the International Conference on Information Systems. Patrick can be reached at P.Finnegan@ucc.ie. 